\title{
TOPICS OF PRE-HOSPITAL CARE FOR SCHOOLCHILDREN: THE PERSPECTIVE OF PROFESSIONALS OF THE MOBILE EMERGENCY CARE SERVICE (SAMU) ${ }^{1}$
}

\author{
Larissa Larie Mota², Selma Regina de Andrade
}

\footnotetext{
${ }^{1}$ Article extracted from the dissertation - Educational instrument for schoolchildren on topics of care for emergencies in the perspective of the professionals of the Pre-Hospital Mobile Emergency Service, undertaken in the Professional Master's Degree in Care Management in Nursing, Universidade Federal de Santa Catarina (UFSC), in 2013.

${ }^{2}$ M.Sc. in Care Management in Nursing. Nurse of the Mobile Emergency Care Service. Florianópolis, Santa Catarina, Brazil. E-mail: larissalariemota@yahoo.com.br

${ }^{3}$ Ph.D. in Nursing. Adjunct Professor of the Department of Nursing and of the Postgraduate Program in Nursing, UFSC. Florianópolis, Santa Catarina, Brazil. E-mail: selma.regina@ufsc.br
}

ABSTRACT: This study aimed to investigate from the perspective of professional SAMU, the main themes of pre-hospital care (PHC), as subsidies for development of an educational tool focused on the school population. A qualitative study, four meetings in the focus group format, with 19 professional SAMU, in a municipality of Santa Catarina, Brazil. Data were categorized and analyzed with thematic analysis. The results highlighted the main issues or health problems of urgent and emergency tool for modeling and possible application in the context of the School Health Program. It was concluded that the selected topics are critical in the context of the APH, the potential severity and the possibility they involve children, even within the school environment.

DESCRIPTORS: Emergency medical services. School health. Health promotion. Health education.

\section{TEMAS DE ATENÇÃO PRÉ-HOSPITALAR PARA INFORMAÇÃO DE ESCOLARES: A PERSPECTIVA DOS PROFISSIONAIS DO SAMU}

RESUMO: Objetivou-se investigar, na perspectiva dos profissionais do SAMU, os principais temas de atenção pré-hospitalar (APH), como subsídios para elaboração de um instrumento educativo voltado à população em idade escolar. Estudo de abordagem qualitativa, por meio de quatro encontros no formato de grupo focal, com 19 profissionais do SAMU de um município catarinense. Os dados foram categorizados e analisados com a técnica de análise temática. Os resultados destacaram os principais conjuntos temáticos de agravos à saúde, de carácter de urgência e emergência para modelagem do instrumento e possível aplicação no contexto do Programa Saúde na Escola. Concluiu-se que os temas selecionados têm importância no cenário do APH, pelo potencial de gravidade e pela possibilidade de acometerem crianças, até dentro do ambiente escolar.

DESCRITORES: Serviços médicos de emergência. Saúde escolar. Promoção da saúde. Educação em saúde.

\section{TEMAS DE ATENCIÓN PREHOSPITALARIA PARA LOS ESCOLARES: LA PERSPECTIVA DE LOS PROFESIONALES DEL SAMU}

\begin{abstract}
RESUMEN: Este estudio tuvo el objetivo de investigar, desde la perspectiva de los profesionales del SAMU, los principales temas de atención pre-hospitalaria (APH), como subsidios para el desarrollo de una herramienta educativa enfocada en la población escolar. Estudio cualitativo, con cuatro reuniones en la modalidad de grupos focales, con 19 profesionales del SAMU, de una ciudad de Santa Catarina, Brasil. Los datos fueron categorizados y analizados con la técnica de análisis temático. Los resultados destacaron las principales cuestiones o problemas de salud de la herramienta de urgencia y de emergencia para el modelado y la posible aplicación en el contexto del Programa de Salud Escolar. Se concluyó que los temas seleccionados son fundamentales en el contexto de la APH, por la gravedad potencial y la posibilidad de involucrar niños, incluso dentro del ambiente escolar.
\end{abstract}

DESCRIPTORES: Servicios médicos de urgencia. Salud escolar. Promoción de la salud. Educación en salud. 


\section{INTRODUCTION}

One of the main indicators of a population's quality of life is its access to the health system; after all, exposure to accidents and other threats to health - such as falls, drownings, burns and poisonings - is increasingly commonplace. ${ }^{1}$ Thus, in Brazil, as in various other countries, the PreHospital Care (APH), having experienced various transformations and the development of complex and specialized technologies, is responsible for the increase in survival of people in serious health conditions, ${ }^{2-3}$ as it allows the first conducts to be taken, as well as enabling referral to the appropriate resource, ideally a specialized one.

A significant component of APH is the Ambulance Service, known in Brazil as the Mobile Emergency Care Service (SAMU), which is characterized by its aim of providing quality mobile emergency care, in any place (homes, workplaces and public highways), through telephone calls to the number 192, 24 hours per day. ${ }^{2,4-5}$

The highest volume of attendances provided by SAMU is for clinical health problems, ${ }^{4}$ including the neurological health problems (fits, cerebrovascular accident (CVA)), the cardiovascular problems (angina, cardiopulmonary arrest (CPA), acute myocardial infarction (AMI) and respiratory problems (asthma, dyspnea, pneumonia), besides attendances relating to syncope or fainting, exogenous poisoning and abdominal pain.

One threat to health of extreme relevance to the $\mathrm{APH}$, and responsible for a significant number of deaths, is represented by traumas. Each year, approximately 130,000 deaths occur in Brazil from intentional external causes (homicides and suicides) or accidents (road traffic accidents, drownings and falls). ${ }^{2}$

The response time for urgent situations and, especially, emergencies, is fundamental for the success of the attendance, as the establishment of the first care measures can mean the difference between life and death. ${ }^{5}$

Cases are common in which, until the ambulance arrives, the doctor responsible for assessing situations and providing advice in the SAMU control center passes on over the telephone the first care measures and maneuvers to be taken for the individual at risk, which will depend on the specific situation of each case. It is in this sense that the first interventions are emphasized and gain importance, as they are responsible for reducing sequelae and suffering.
In general, this first attendance is undertaken by the person who requests help from the SAMU, as the interlocutor for the person who suffered the health problem, with the support of the advice and referrals given by the doctor providing assessment and advice in the SAMU center. For this, notions regarding emergency care can and must be spread, not only among professionals of the health area, but also among the population in general. In this study, emphasis is placed on the school-age population, given that this is already able to assimilate objective information and assist in undertaking the first measures of care in emergency situations, which can occur with oneself or others. Besides this, when advised correctly, schoolchildren are able to intervene positively or, further, to adopt measures regarding prevention for health problems and risk situations.

Intersectorial actions can be triggered as a strategy for achieving objectives of accident prevention in childhood. ${ }^{6}$ Brazil's School Health Program (PSE) ${ }^{7}$ supports this premise, establishing a partnership between the professionals of the Family Health Strategy and schools, for the undertaking of activities which make them co-responsible for their health condition and empower them for assertive decision-making in relation to their health and to the health of the community in which they are inserted.

Through questioning regarding which emergency situations could be addressed in the schoolage population, this study sought to investigate, in the perspective of the SAMU professionals, and based in the literature, the main topics of prehospital care to be addressed with that population. The topics brought up have the aim of supporting the development of an educational instrument geared towards the school-age population.

\section{METHOD}

This study, with a qualitative approach, was undertaken using the technique of meetings in the format of the Focus Group (FG), which makes it possible to obtain qualitative information through informal discussions among a group of people with characteristics in common, in which the researcher acts as an encourager in the exchanging of interpersonal information. ${ }^{8}$

Of a total of 48 professionals invited (20 physicians, 05 nurses, 09 nursing technicians and 14 ambulance drivers), 19 agreed to participate, these being 4 nursing technicians, 4 staff nurses, 
9 ambulance drivers and 2 emergency physicians. All worked in direct care for the community, as part of Basic Life Support Unit (USB) teams or the Advanced Life Support Unit (USA).

Four FGs were held, based in the base of the on-duty teams in the SAMU of a city in the Brazilian State of Santa Catarina, between the months of October and November 2012. Authorization was obtained for sound-recording all the meetings, which were led by one of the researchers and a collaborator, invited to undertake the role of observer, recording the non-verbal communication in the discussions, without contributing, in relation to difficulties, interactions and spontaneity of the participants in the discussions.

The meetings were guided by key-questions, as well as by the use of a topics guide, defined by general questions which lead the discussions towards matters which need to be addressed. ${ }^{8}$ The topics guide was made up of central topics, that is, autonomous questions central to the discussion, besides subcategories or specific issues, related to the central theme, and stimuli, such as figures, cartoons, videos, etc, whose images had to do with the central issue of the meeting. ${ }^{8}$ These resources were presented using multimedia (Microsoft PowerPoint $\left.{ }^{\circledR}\right)$, making adequate visualization by the group possible.

The audio files were transcribed and grouped. The data were categorized in accordance with the central theme and the information was treated and interpreted, using the technique of thematic analysis, ${ }^{9}$ which included: a) pre-analysis, through skim reading, aiming for the organization of the information transcribed; b) exploration of the content, producing the coding, the classification and the categorization of the topics suggested by the participants; and c) the treatment and the interpretation of the results, in which it was sought to highlight the topics identified, in the light of the literature. The thematic analysis of the FGs resulted in four thematic categories, grouped with the following titles: The SAMU and the school: education and health promotion for children; How SAMU functions: what is important to know?; Something is wrong, what do I do now?; and We are nearly finishing, give your opinion.

The surveying of the topics proposed for making up an educational instrument, for children inserted in the context of the PSE, was deepened in the third meeting of the FG. In this, with the central topic questioning regarding "what urgent and emergency situations do you highlight to be addressed with the school-age population?", The results were grouped in the thematic category entitled "Something is wrong, what do I do now?".

It was from this category that the main threats to health, with an urgent and emergency character, attended in the scenario of the $\mathrm{APH}$, and which the SAMU professionals considered important for making up an educational instrument for schoolchildren, resulted.

These threats to health listed with greater emphasis in the third FG, due to their relevance, were re-grouped, categorized and systematized for discussion with the literature, in accordance with the sequence suggested by the FG: Fainting, covering fits (epilepsy) and cardiopulmonary arrest (CPA); Hypoglycemia and hyperglycemia; Foreign Body Airway Obstruction (FBAO); Accidents, covering road traffic accidents and domestic accidents (venomous animals, poisonings and burns). Each one of these topics constitutes a keyword for searching using the Google Scholar ${ }^{\circledR}$ search engine. Only the topics of AMI and CVA were not included in this study, due to their low incidence among children and the school environment.

The study was approved by the Committee for Ethics in Research with Human Beings, under Opinion $\mathrm{n}^{\circ} 144.453 / 12$. The accounts were validated by the participants, via e-mail, and were presented in this study as R1 (Respondent 1), R2 (Respondent 2) and so on.

\section{RESULTS AND DISCUSSION}

The topics proposed by the FG for making up an educational instrument geared towards the school-age population were selected because they dealt with emergency health issues, important in the scenario of $\mathrm{APH}$, considering the role which the schoolchildren can perform in this context, as in the account: [...] We know of cases in which children made the difference in the attendance (R4).

The topics were established by the FG empirically, that is, based on the frequency and the occurrence of the attendances undertaken during the routine workday, and are characterized in table 1.

Although other topics have been surveyed, this study presents and discusses those thematic sets highlighted in the literature, due to their relevance due to their affecting children, or occurring in their presence, or even within the school environment. 
Table 1 - Main topics of pre-hospital care for the construction of an educational instrument for schoolchildren, according to the professionals of the SAMU, 2012

\begin{tabular}{|l|l|l|}
\hline \multicolumn{1}{|c|}{ Characterization } & \multicolumn{1}{c|}{ Specific topics } & \multicolumn{1}{c|}{ Subtopics } \\
\hline My God, he has fallen! & Fainting & $\begin{array}{l}\text { Fits } \\
\text { Cardiopulmonary arrest (CPA) }\end{array}$ \\
\hline He is snoring, is he sleeping? & Hypoglycemia and hyperglycemia & None \\
\hline He has choked, what do I do now? & Foreign Body Airway Obstruction (FBAO) & None \\
\hline What has happened here? & Accidents & $\begin{array}{l}\text { Domestic accidents } \\
\text { Poisonings } \\
\text { Venomous animals } \\
\text { Burns }\end{array}$ \\
\hline
\end{tabular}

\section{"My God he has fallen!" - fainting, fits (epilepsy) and cardiopulmonary arrest}

Fainting has various causes and two hazards to health can be confused with this: epilepsy and the CPA. These stand out from the others because of their high incidence and the seriousness and imminent risk of death which they entail. The FG chose to address these topics with the aim of analyzing the child population in differentiating between fainting and losing consciousness, whether due to an episode of an epileptic fit or because of CPA. In this last case, the rapid and correct identification are the first links in the chain of survival.

Epilepsy is considered the most common chronic and serious neurological condition worldwide, affecting all age ranges, irrespective of the individual's race and purchasing power, and has a high rate of incidence and prevalence in childhood and adolescence. ${ }^{10-12}$ The most frequent crises are of the generalized tonic-clonic type, characterized by the loss of consciousness, rigidity and muscular spasm, generally accompanied by the relaxation of the sphincters, as well as by oral bleeding due to the possibility of biting the tongue. This fact is responsible for the myth that, during the crisis, it is possible to swallow the tongue, as expressed in the account: I have attended persons with cuts on their hands because they had gone to help somebody who was convulsing and they put their hand in the person's mouth, to try to hold the tongue. So we explain that this doesn't happen, but they say that it can (R7).

Teachers, parents, family members and caregivers, guided by inadequate knowledge and their beliefs, continue to perpetuate the habit of introducing one's own fingers into the mouth of a person who is experiencing an epileptic fit and, sometimes, they use objects such as rulers and pens, resulting in important injuries to the epileptic person's oral cavity, sometimes causing the loss of teeth. ${ }^{10-12}$ The impossibility of predicting the occurrence of the crises and the lack of knowledge regarding the pathology contribute to causing discomfort and fear when helping. ${ }^{10}$

One study ${ }^{12}$ reveals that in approximately $40 \%$ of cases of epilepsy, appropriate treatment is not undertaken, resulting in routine care in the primary care services and in Emergency Rooms. In order to change the scenario of prejudice, beliefs and stigmas, this study's results point to the need for educational proposals aimed at the school community (students and teachers), the community in general, and also the professionals from the area of health.

The CPA is considered a medical emergency of great seriousness, characterized by the absence of heartbeat and respiratory movements due to the abrupt cessation of the circulation and respiration. It causes unconsciousness, irreversible brain damage and death in those cases in which measures for re-establishing these functions are not applied at an early stage and efficaciously. ${ }^{13-14}$ The cardiovascular diseases, with emphasis on the ischemic diseases, are responsible for approximately $30 \%$ of deaths in Brazil, occurring mainly in the pre-hospital setting. The "chain of survival" is a care strategy constituted by links which include the recognition of the situation of absence of heartbeat and the immediate request for help, as well as techniques of basic and advanced life support. ${ }^{13-14}$

In this study, the FG indicated the relevance of sensitizing the schoolchildren regarding how to identify a CPA, so as to initiate the first link in the chain, which is important as it is responsible for triggering the others and, if undertaken correctly, can afford the individual a chance of survival. The accounts illustrate this fact: [...] identifying a CPA, at a very early point, is more important than knowing what you have to do. Following that, you request help (R11); I think that there could be an addendum [...] how to check if the person is breathing (R4). 
The response time, which consists of the time between the call for the emergency service and the arrival of the professionals in the place of occurrence, needs to be triggered as fast as possible, and neither of these occur unless the first link in the chain is begun. Thus, the education of the population, including children, is emphasized in the sense of contributing to the recognition of serious signs of threat to life, and to intervene correctly and efficaciously until the arrival of help. ${ }^{14}$

\section{"He is snoring, is he sleeping?" - Hypoglycemia and hyperglycemia}

For people with either diabetes mellitus (DM) type I or type II, situations of hypoglycemia and hyperglycemia, whether acute or chronic, are harmful in the short and long-term and, although caused by different mechanisms, the maintenance of appropriate glycemic levels is a daily challenge. The account below emphasizes the importance of this topic.

In the item on hypoglycemia and hyperglycemia... of course, hypoglycemia has to be well defined and publicized, mainly for the children who live with somebody who is diabetic. As a result, they need to be able to identify the symptoms, which are not difficult to learn about and recognize. Hyperglycemia is more complicated to identify, and the person herself is able to request help. The most common, however, is hypoglycemia (R4).

In hypoglycemia, the symptoms presented vary from palpitations, tachycardia, tremors, sudoresis, anxiety, paresthesias, headache, somnolence, dizziness, asthenia, confusion, irritability and behavioral changes, through to more serious situations such as focal neurological deficits, convulsions and coma. ${ }^{15-17}$ Hypoglycemia can occur in fasting, due to the use of medications, situations of infection, and insulinoma; however, it can also occur after meals (post-prandial), due to rapid gastric emptying and the ingestion of alcoholic drinks, among others. ${ }^{15,17}$ It is common for the SAMU to attend individuals with hypoglycemia, as shown by the following account: [...] It happened to me, recently, like this: we arrived there and [...] they had already given first aid, and perceived that it was a case of hypoglycemia, as a result of which they had requested our support. We arrived there and the neighbor said straightaway: it's the diabetic, who is having an attack [...] they had given him more insulin and when we arrived, the guy was sweating profusely, snoring... they had complicated the guy's situation even more (R11).
This mistake can generate serious complications. Under-informed people can harm a person whose health has already been weakened by DM, as exemplified in the following account: it has already happened with me, and must've happened with you as well... the guy was already unconscious because of the hypoglycemia, and his neighbor was there with him, his mother-in-law, putting something down his throat... and soon after he aspirated, and, what is more, worsened the situation. [...] and what had been a case of hypoglycemia ended up becoming an obstruction of the airways (R11).

One study ${ }^{18}$ reveals that, in conjunction with the use of medications, the majority of diabetics do not follow the correct guidance regarding the practicing of regular physical exercise in order to help in correcting the plasma glucose values. This fact is verified by the recurrent hypoglycemic crises during or following activities, precisely because of the organic mismatch of a poorly-organized activity. In the child population, this directly affects socialization among the children, both within and outside the school environment. The morning break/playtime is, for many, a time to relax and play with friends, besides the physical education classes themselves. Episodes of hypoglycemia, as well as other health problems, can occur inside the school and, for this reason, staff, teachers and students need to know what to do when faced with urgent and emergency situations.

Hyperglycemia is also characterized as a situation of serious metabolic disorder, although it is less frequent in young people. Diabetic ketoacidosis affects between 20 and $30 \%$ of children and adolescents, and $17 \%$ of adults. The hyperglycemic hyperosmolar state, on the other hand, occurs with greater frequency in adults aged over 50 years old. ${ }^{17}$

\section{"He has choked, what do I do now?" - foreign body airway obstruction}

Foreign body airway obstruction (FBAO) presents, among other causes, a mechanical origin, caused by foreign objects aspirated accidentally during the occurrence of face trauma (teeth and dental prostheses), eating (bones and chewing gum), and also during moments of distraction, such as when a child places small objects/toys in the mouth, or, in adulthood, paperclips, etc.

Accidents caused by aspirating foreign bodies are characterized by potentially fatal episodes, whose seriousness, represented by the presence 
of cyanosis, is directly related to the extent of the obstruction of the airways. ${ }^{19}$ Individuals with asphyxia caused by partial or total obstruction of the trachea and larynx mainly progress to death in few minutes. ${ }^{20}$

The participants in the FG showed the importance of this topic making up the educational instrument: the following account shows the relevance of disseminating the first steps to be taken when faced with a situation of choking. FBAO is important [...]. It is a situation which consolidates very fast. We have little time to act. They have to know it and recognize it and they have to know what to do until help arrives (R4).

In childhood, accidents involving aspirating foreign bodies mainly occur when children handle small toys and certain foods, mainly grains and seeds. One study ${ }^{19}$ notes that this occurrence is most common in children aged below three years old, in whose case diagnosis becomes more difficult when the parents or guardians did not witness the scene. Another study ${ }^{21}$ indicates that, in pediatric emergencies, aspiration of foreign bodies is responsible for a large number of attendances, due to the serious respiratory discomfort which generally accompanies the situation. That study reinforces the importance of early diagnosis and intervention, due to the complications and respiratory sequelae, such as, for example, recurrent pulmonary infections.

\section{"What has happened here?" - domestic accidents, poisonings, accidents with venomous animals and burns}

In Brazil, as elsewhere in the world, injuries resulting from external intentional causes (incidents of violence, acts of aggression, homicides, suicide and negligence) or accidents (road traffic accidents, drownings, falls, burns) are responsible for a significant number of deaths and constitute a public health problem. ${ }^{22}$

An accident is defined as an occurrence which occurred by chance, whether fatal or not, but which could have been avoided. ${ }^{23}$ It can occur either in the domestic environment or in social environments and, when serious, requires specialized attendance, with important physical or psychological sequelae remaining in the majority of cases.

In relation to the child population, although the road traffic accidents - principally involving bicycles - are important, emphasis again falls upon the domestic accidents, due to the broad range of possibilities, throughout the long periods in which they remain in their homes, and to the highest potential for severity, when compared with road traffic accidents.

In Brazil, each year, approximately 140,000 children aged 12 to 14 years old are hospitalized, with approximately 6000 dying, due to trauma, drownings, burns and poisoning, even when they are treated in emergency units. ${ }^{24}$ Due to the specific characteristics of cognitive development (immaturity for foreseeing situations of danger) and motor development (lack of coordination), among others, accidents involving children have been studied with the aim of identifying the predisposing and predominant factors, as well as the respective intervention strategies. ${ }^{24}$ The accounts below reveal the FG's concern with addressing these topics: [accidents] with children are going to involve bicycles, swings, slides, domestic accidents (R9); falls are also important (R7).

The domestic accidents are those which predominate when one analyzes the involvement of children and adolescents: the majority are caused by penetrating or aspirated objects (coins, grains, seeds, among others) and animals (mainly dogs). The deaths which occur in the home, on the other hand, for the same population, are due to falls, drownings, poisonings and asphyxia, among others. ${ }^{6,23}$

Poisonings account for a large volume of attendances undertaken in emergencies for adults and children. They constitute a set of signs and symptoms caused by the interaction between the chemical agent and the biological system..$^{24}$ The chemical substances may be in plants, venomous animals, pesticides, medications and industrial or domestic products.

Within the group of cases of poisoning, children, along with the female population, are the people most affected by this event. This greater exposure is due to the ease of access and time spent in the home (in the case of children) or due to involvement in cleaning activities with household cleaning products (in the case of women). ${ }^{25}$ One study indicates medications as the main agent causing poisonings in childhood, followed by household cleaning products, which mainly occur by mouth..$^{24}$ The following account illustrates an alert to the problem.

In one job we did, my wife found a really good picture about this. On one side, you see the chemical products: washing powder, tablets, and bottles of chemical products. In the same image, they transformed those 
bottles into animals: a little elephant, a giraffe [...] It was brilliant! How the adult sees it and what the child sees. How that image called our attention [...] in this case of poisoning (R4).

Accidents with venomous animals are also characterized as domestic accidents and can also result in poisoning, depending on the aggressive agent involved, such as spiders and scorpions, among others. Children constitute the proportion of the population which is most involved in these occurrences, due to characteristics inherent to their development, such as constantly being in activity, and their curiosity. The FG participants mentioned to [include in the educational instrument] accidents with venomous animals, because children mess with animals... spiders... ( R6); and [provide guidance regarding] taking care when in places with stones, or a dog which you don't know. Basic things like this (R9).

Mortality rates due to wounds in childhood increase as the child grows. Burns represent a significant proportion of these rates. These mostly occur through the spilling of hot liquids (water and coffee), contact with hot surfaces (the oven, saucepans) and electricity (shocks). These are most frequent among boys, aged up to four years old, in the home environment, mainly in the kitchen. ${ }^{26-28}$ Generally speaking, the victims of burns result in a significant number of episodes of inpatient treatment, with rates of $18.1 \%$, while those from falls reach close to $8 \%$, and those from road traffic accidents, a little over $16 \% .^{27}$

Children of school age are also exposed to risks for accidents due to burns. One study ${ }^{28}$ concluded that burns victims with the largest body surface area compromised were in the age range between 5 and 13 years old, mainly caused by the combustion of alcohol*. This finding is explained by the fact that, in this age range, children experience independence and autonomy, and gradually come into contact with flammable substances, fireworks, and electrical equipment, both inside and outside the house. The following account demonstrates this: I attended a child who had been frying potato, alone, far from her father... Using the stove... an adolescent of 12 years old. So she got burned, third-degree burns, just to say. Everything you shouldn't do, she did: she rubbed on cream, she covered it with stuff. By the time we got there... God, it was looking bad (R6).

Studies emphasize the importance of undertaking educational activities relating to the seriousness and the risks of accidents from burns, directly with the children, within the school environment, ensuring that they receive objective information, with language and content appropriate to their ages and ability to understand, as they are able to grasp and process guidance and to make deductions. ${ }^{26-27}$ This concern was shared by the FG participants:

I think that when giving advice on burns, it is appropriate to talk about, and show, what the complications are in the medium and long terms. If it was a burn covering a large area, the person dies from " $n$ " complications. Show the scars, the restrictions on movement... All that stuff which we already know (R11).

The FG participants also expressed the idea of passing on to the children the correct knowledge regarding what to do after the accident occurs, as some practices can result in serious complications for the wounds, which can range from delaying the process of healing through to contaminating the wound, as in the case, for example, of applying chalk dust, coffee, margarine, or egg white.

\section{FINAL CONSIDERATIONS}

Appropriate attendance, in the first minutes which followed the harm to health, can be responsible for increasing survival and minimizing sequelae in the individuals in urgent or emergency situations. For this, it is necessary that such actions should be broadly publicized, so that setbacks in the issue should not occur, that is, so that they may not cause harm to the people who have already been weakened.

This study resulted in the investigation of the main forms of harm to health which strike adults and also children, these being: fainting, fits (epilepsy), cardiopulmonary arrest, hypoglycemia, hyperglycemia, obstruction of the airways by a foreign body, domestic accidents, poisonings, accidents with venomous animals, and burns. These forms of harm to health, if not attended early and efficaciously, present a risk to life due to their impact on the individuals' safety and maintenance of life.

To this end, the importance is emphasized of putting into effect educational strategies undertaken with the community in general and, mainly, with children, so as to try to change the negative statistical context indicated by the studies. This study considered the involvement of children

* The use of alcohol-based cleaning fluids is very common in Brazil. Translator's note. 
and adolescents in urgent and emergency health problems, not only as victims, but also as people, capable of taking on another role in these events: that of the provider of first aid to those who are around them, such as friends, family members and even strangers, so long as they are instrumentalized by a knowledge based in correct notions and practices, regarding what must be established soon after the occurrence of an event which places at risk their life or that of other people; this in addition to raising their awareness regarding the notion of anticipating situations of risk, through adopting simple yet efficient measures.

The school environment stands out as a privileged locus for health education, as it receives individuals who are growing, and because it constitutes a scenario where many forms of harm to health occur, no less serious because they affect children and adolescents. The main topics in emergency care, for addressing with the schoolage population, investigated in this study, corroborate studies which demonstrate the importance of involving this population in first aid. The set of these, and of other forms of harm to health, listed by the FG, was included in the text of the educational instrument, available online at http:/ / www. jolimack.com/larissa/cartilha_tio_samu.pdf, and on the site of the Professional Master's Degree in Care Management in Nursing, of the UFSC.

\section{REFERENCES}

1. Souza RM, Morabito R, Chiyoshi FY, Iannoni AP. Análise da configuração de SAMU utilizando múltiplas alternativas de localização de ambulâncias. Gest Prod. 2013 Jun; 20(2):287-302.

2. Simões RL, Duarte NC, Maciel GSB, Furtado TP, Paulo DNS. Atendimento pré-hospitalar a múltiplas vítimas com trauma simulado. Rev Col Bras Cir. 2012 Jun; 39(3):230-7.

3. Schweitzer G, Nascimento ERP, Nascimento KC, Moreira AR, Bertoncello KCG. Protocolo de cuidados de enfermagem no ambiente aeroespacial à pacientes traumatizados: cuidados durante e após o voo. Texto Contexto Enferm [online]. 2011 Set [acesso 2014 Fev 28]; 20(3):478-85. Disponível em: http://www.scielo.br/scielo.php?script=sci arttext\&pid=S0104-07072011000300008\&lng=pt

4. Marques GQ, Lima MADS, Ciconet RM. Agravos clínicos atendidos pelo Serviço de Atendimento Móvel de Urgência (SAMU) de Porto Alegre-RS. Acta Paul Enferm. 2011; 24(2):185-91.

5. Souza RM, Morabito R, Chiyoshi FY, Iannoni AP. Extensão do modelo hipercubo para análise de sistemas de atendimento médico emergencial com prioridade na fila. Prod [online]. 2014 Mar [acesso 2014 Jun 20]; 24(1):1-12. Disponível em: http:/ / www. scielo.br/scielo.php?script=sci_arttext\&pid=S010365132014000100001\&lng=pt\&nrm=iso

6. Del Ciampo LA, Ferraz IS, Tazima MFGS, Bachette LG, Ishikawa K, Paixão R. Características clínicas e epidemiológicas de crianças acidentadas atendidas em um serviço de pronto-atendimento. Pediatr (São Paulo). 2011; 33(1):29-34.

7. Brasil. Decreto n. 6.286, de 5 de dezembro de 2007. Institui o Programa Saúde na Escola - PSE, e dá outras providências. Diário Oficial da República Federativa do Brasil, 06 Dez 2007. Página 2 [acesso 2012 Mar 19]. Disponível em: http://www.planalto.gov.br/ ccivil_03/_ato2007-2010/2007/decreto/d6286.htm

8. Barbour R. Grupos focais. Porto Alegre (RS): Artmed; 2009.

9. Bardin L. Análise de conteúdo. Lisboa (PT): Edições 70; 2010.

10. Fernandes PT, Souza EAP. Percepções do estigma da epilepsia em professores do ensino fundamental. Estud Psicol [online]. 2004 Abr [acesso 2013 Set 05]; 9(1):189-95. Disponível em: http:/ / www.redalyc. org/pdf/261/26190120.pdf

11. Fernandes PT, Noronha ALA, Hansen JR, Li ML. Perception and attitudes towards epilepsy: point of view of professionals allied to medicine from Mobile Emergency Service in Campinas. J Epilepsy Clin Neurophysiol [online]. 2009 Sep [access 2013 Sep 05]; 15(3):119-22. Available from: http:/ / www. scielo.br/scielo.php?script=sci_arttext\&pid=S167626492009000300005\&lng=en\&nrm=iso

12. Magalhães LVB, Fernandes PT, Li LM. Aspectos educacionais na epilepsia. J Epilepsy Clin Neurophysiol. 2009; 15(4):172-7.

13. Morais DA, Carvalho DV, Timerman S, Gonzalez MMC. Parada cardiorrespiratória em ambiente préhospitalar: ocorrências atendidas pelo serviço de atendimento móvel de urgência de Belo Horizonte. Rev Bras Clin Med. 2009; 7(4):211-8.

14. Semensato G, Zimerman L, Rohde LE. Avaliação inicial do Serviço de Atendimento Móvel de Urgência na Cidade de Porto Alegre. Arq Bras Cardiol. 2011 Mar; 96(3):196-204.

15. Felício JS, Martins CP, Semer M, Kalinin L, Nery M, Machado MCC, et al. Hiperinsulinismo endógeno: revisão e seguimento de 24 casos. Arq Bras Endocrinol Metab [online]. 2012 Mar [acesso 2013 Set 05]; 56(2):83-95. Disponível em: http://www. scielo.br/scielo.php?script=sci_arttext\&pid=S000427302012000200001\&lng=en\&nrm=iso

16. Liberatore Junior RDR, Negri AA, Martinelli Junior CE, Kochi C, Silva IN, Collett-Solberg PF. Hipoglicemia hiperinsulinêmica da infância: análise de dados clínicos de uma amostra brasileira. Arq Bras Endocrinol Metab [online]. 2012 Dez [acesso 2013 Set 05]; 56(9):666-71. Disponível em: http:/ / www. 
scielo.br/scielo.php?script=sci_arttext\&pid=S000427302012000900011\&lng=en\&nrm=iso

17. Martins HS. Emergências clínicas: abordagem prática. $8^{\mathrm{a}}$ ed. Barueri (SP): Manole; 2013.

18. Miculis CP, Mascarenhas LP, Boguszewski MCS, Campos W. Atividade física na criança com diabetes tipo 1. J Pediatr (Rio J.) [online]. 2010 Aug [acesso 2013 Set 05]; 86(4):271-8. Disponível em: http:/ / www.scielo.br/scielo.php?script=sci_ arttext\&pid=S0021-75572010000400005\&lng=en\& nrm $=$ iso

19. Fraga AMA, Reis MC, Zambon MP, Toro IC, Ribeiro JD, Baracat ECE. Aspiração de corpo estranho em crianças: aspectos clínicos, radiológicos e tratamento broncoscópico. J Bras Pneumol [online]. 2008 Fev [acesso 2013 Set 05]; 34(2):74-82. Disponível em: http:/ / www.scielo.br/scielo.php?script=sci_ arttext\&pid=S1806-37132008000200003\&lng=en\& nrm $=$ iso

20. Rodrigues AJ, Oliveira EQ, Scordamaglio PR, Gregório MG, Jacomelli M, Figueiredo VR. Broncoscopia flexível como primeira opção para a remoção de corpo estranho das vias aéreas em adultos. J Bras Pneumol [online]. 2012 Jun [acesso 2013 Set 05]; 38(3):315-20. Disponível em: http://www.scielo.br/scielo.php?script=sci_ arttext\&pid=S1806-37132012000300006\&lng=en\& $\mathrm{nrm}=\mathrm{iso}$

21. Veras TN, Hornburg G, Schner AMS, Pinto LA. Uso da broncoscopia virtual em pacientes pediátricos com suspeita de aspiração de corpo estranho. J Bras Pneumol [online]. 2009 Set [acesso 2013 Set 05]; 35(9):937-41. Disponível em: http://www. scielo.br/scielo.php?script=sci_arttext\&pid=S180637132009000900016\&lng=en\&nrm=iso

22. Mascarenhas MDM, Silva MMA, Malta DC, Moura L, Gawryszewski VP, Costa VC, et al. Atendimentos de emergência por acidentes na rede de vigilância e acidentes - Brasil, 2006. Ciênc Saúde Coletiva [online]. 2009 [acesso 2013 Set 04]; 14(5):1657-68. http:/ / www.scielo.br/scielo.php?script=sci_ arttext\&pid=S1413-81232009000500007

23. Pedrosa AAG, Mascarenhas MDM, Costa EM, Cronemberger LP. Atendimentos por causas acidentais em serviços públicos de emergência Teresina, Piauí - 2009. Ciênc Saúde Coletiva. 2012 Set; 17(9):2269-78.

24. Tavares EO, Buriola AA, Santos JAT, Ballani T, Silva L, Oliveira MLF. Fatores associados à intoxicação infantil. Esc Anna Nery [online]. 2013 Mar [acesso 2013 Set 05]; 17(1):31-7. Disponível em: http:/ / www. scielo.br/scielo.php?script=sci_arttext\&pid=S141481452013000100005\&lng=en\&nrm=iso

25. Fook SML, Azevedo EF, Costa MM, Feitosa ILF, Bragagnoli G, Mariz SR. Avaliação das intoxicações por domissanitários em uma cidade do Nordeste do Brasil. Cad Saúde Pública [online]. 2013 Mai [acesso 2013 Set 05]; 29(5):1041-5. Disponível em: http:/ / www.scielo.br/scielo.php?script=sci_ arttext\&pid=S0102-311X2013000500021\&lng=en\& nrm=iso

26. Cartaxo ANB, Alencar AMPG, Sampaio KJA, Oliveira JD. Caracterização dos casos de queimaduras infantis em hospital materno infantil de referência municipal. Cad Cult Ciênc [online]. 2011 Dez [acesso 2013 Set 04]; 10(1):45-53. Disponível em: http:// periodicos.urca.br/ojs/index.php/cadernos / article/view/270/165

27. Gawryszewski VP, Bernal RTI, Silva NN, Morais Neto OL, Silva MMA, Mascarenhas MDM, et al. Atendimentos decorrentes de queimaduras em serviços públicos de emergência no Brasil, 2009. Cad Saúde Pública. 2012 Abr; 28(4):629-40.

28. Millan LS, Gemperli R, Tovo FM, Mendaçolli TJ, Gomez DS, Ferreira MC. Estudo epidemiológico de queimaduras em crianças atendidas em hospital terciário na cidade de São Paulo. Rev Bras Cir Plást. 2012 Dez; 27(4):611-5. 